Arslan, H. ve Özbay, R. D. (2015). İktisadî ve siyasî etkenlerle Osmanlı'da dış göç: 16. yüzyılda mühimme defterlerinde, Sosyoloji Dergisi, 3. Dizi, 30. Sayı, 2015/1, 397-424.

\title{
İktisadi ve Siyasi Etkenlerle Osmanlı’da Dış Göç: 16. Yüzyılda Mühimme Defterlerinde
}

\author{
Hüseyin Arslan*, Rahmi Deniz Özbay ${ }^{* *}$
}

Özet: Nüfus kazanma veya yitirme anlamına gelen dış göçün, 16. asırda Osmanlı'da, hangi etkenlerle yaşandığı sorgulandı. Dışardan göçerek gelen ve Osmanlı'dan dışarıya göç edenlerin hangi etkenler altında yer değiştirdikleri hakkında bilgi edinmek amaçlandı. Sınırlı sayıda Mühimme Defteri tarandı. İkincil kaynaklarla desteklendi. Hükümlerin; transkripsiyonu verildikten sonra günümüz Türkçesi ile özeti ve ana teması verildi. Bazı belgelerde sadeleştirme yapıldı. Doğuda Sâfevî İranı, Batıda ise Macaristan-Avusturya sınır bölgelerinde, nüfus hareketliliği işlendi. Uygulamada birlik, bütünlük, hukuka uygunluk, adalet ve uyum ilkeleri görüldü. Dışarıya göçün istenmediği, önlenmesi amacıyla tedbirlerin alınmasının yöneticilerden talep edildiği görülmüştür. Nüfus hareketlerinin; güvenlik arayışı, yaylak-kışlak yerlerinin yöneticiler tarafından başkalarına verilmesi, vergi yükünün ağırlığı, dışarıdan nüfus çağrılması, bir idarecinin verilen yerleri beğenmemesi, rea’âyadan bir kısmının Safevîlere katılma faaliyetleri, üç yıla kadar vergi muafiyeti, iç kesimlerden nüfus çekilmesi gibi ekonomik, politik, idari, sosyal ve mezhebî sebeplere dayandığı anlaşılmıştır. Nüfusun bulunduğu yerde yaşamasını teşvik edici, refah şartlarını sağlayan, ülkede kalmasını sağlayıcı nüfus politikalarının uygulanması önerilmiştir.

Anahtar Kelimeler: Göç, Nüfus Hareketleri, Aşiretler, Sâfevî, Osmanlı, Bozulus, Karaulus.

\section{Emigration in the Ottoman State due to Economic and Political Factors: In the Muhimmah Books in the 16th Century}

\begin{abstract}
In the 16th century's Ottoman, external migration, which means winning or losing population, were questioned to originate from which factors. Gaining information about, under which factors, the migrate from the outside and migrating out of the Ottoman replaced each other, were aimed. The provisions of a limited number of Muhimmah were screened and was supported by secondary sources. After the transcription of the provisions were given, summary and main theme were given with today's Turkish. Simplification was made in some documents. It was seen to be demanded from the concerned state officials that the required measures be taken for the prevention of population movements, the population mobility in Safavid Iran in the East and on the borderland between Hungary and Austria in the West, were processed. In practice, unity, integrity, legality, justice and harmony principles were observed. The population movements were based on such reasons as economical, political, administrative, social and denominational; with the purpose of search for security; that the summer pastures and winter quarters were seized of them by the rulers to be transferred to some others for diverse reasons; the heavy burden of taxes; invited population from abroad; that those places allocated were considered to be insufficient by some administrators; the attempts of some people to join the Safavids; offering tax exemption up to three years and drawing populations from inlands. The implementation of the population policy that, encourages the population living in the place they are, providing welfare requirements, has been proposed.

Key Words: Emigration, Population Movements, Ashirats, Safavid, Ottoman, Bozulus, Karaulus.

\footnotetext{
* Yrd. Doç. Dr. İstanbul Ticaret Üniversitesi, Meslek Yüksek Okulu, harslan@ticaret.edu.tr

* Doç. Dr. Rahmi Deniz ÖZBAY, Marmara Üniversitesi, İktisat Fakültesi, İktisat Bölümü, rahmideniz@marmara.edu.tr
} 


\section{Giriş}

\section{Göç ve Türleri}

Göç, kişi veya kişilerin gelecekteki hayatlarının tamamını veya bir parçasını geçirmek üzere, tamamen yahut geçici bir süreliğine bir iskân ünitesinden (şehir, köy gibi) diğerine yerleşmek üzere yaptıkları coğrafi yer değiştirme hadisesidir. Bu nüfus hareketinin oluşmasında rol oynayan, hareketi sağlayan faktörler açısından göçü iki şekilde incelemek mümkündür: İnsanoğlunun serbest iradesi ile gerçekleşen göç ve güdümlü veya otoriter bir baskı altında gerçekleşen zorunlu göç. Göçler, doğrudan doğruya ülkelerin veya daha küçük toplulukların nüfusunun artma veya azalma yönünde gelişmesini etkileyen, nüfusun nitelik ve nicelik bakımından yapısını değiştiren önemli faktörlerden biridir. Nüfusun yaş, cinsiyet, vasıf ve kalite yapısında değişmeye sebep olurlar. Bu değişmeler göç alan ve göç veren çevrelerde birbirine zit yönde etkiler bırakır. Göçe konu olan fert veya kütlelerin nitelik yapısına göre değişimler gerçekleşir göç (Akkayan, 1979, s. 20).

Göçün olumlu ve olumsuz etkileri vardır. Göçün; ekonomik imkânlarla nüfus arasında denge sağlayan, aynı zamanda insanların, yetenek ve uzmanlıklarından en etkin biçimde faydalanmayı mümkün kılan; kişilerin sosyal, siyasal, ekonomik, teknolojik, eğitimsel, kültürel, psikolojik arzularının tatminine imkân veren olumlu bir mekanizma olduğunu tespit etmek mümkündür. Problemlerle dolu bir bünye kazanması halinde ise mekanizmanın olumsuz bir işleyişe yöneleceği de söylenebilir göç (Akkayan,1979, s.21).

Bir sosyal hareketlilik (Tuna,1981,s.245-252) türü olan göç olayı: iç göç ve

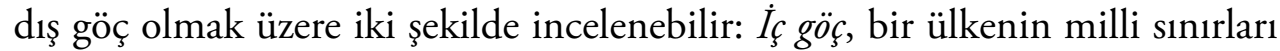
içinde, $d \iota s ̧$ gö̧̧ de ülkelerin milli sınırlarını aşarak (her iki yönde de olabilir, milli sınırların içinden dışarıya veya milli sınırların dışından içine doğru), tanımlarda belirtilen özelikleri taşıyan nüfus hareketleridir. "Bir memleket hudutlarını her iki istikamette aşmak suretiyle meydana gelen ve çalışmak, yerleşmek maksadıyla yapılan nüfus hareketine $d \imath ̧ ̧$ göç (external migration) veya aynı anlama gelmek üzere beynelmilel gö̧̧ (international migration) adı verilir göç (Akkayan,1979, s.21).

Dış göçün bir başka boyutu ise nitelikli insan göçüdür. Burada her türlü nitelikli, topluma katma değer katabilecek insan ve nüfusun ülke dışına çıkışı söz konusudur. Bunun bir başka adı beyin göçüdür (Kurtuluş, 1999,s.XVXIX). Yine mevsimlik göç ve daimi göçten de söz edilebilir. Mevsimlik göçte; göç edilen yörenin (kaynak noktasının) ekonomik faaliyetinin yoğun olduğu süre dişındaki zamanlarda kişilerin yerlerini gelecek döneme kadar terk edip, diğer bölgelerde çalışmaya gittikleri göç türüdür. İkinci türde ise belirli bir süre söz konusu olmayıp, daimi yerleşmeden söz edilir (Akkayan, 1979, s. 24). 


\section{Mübimme Defterleri’nin Önemi}

Osmanlı Devleti'nin müesseselerine, uygulamalarına ve benzeri birçok alanda tarihine ışı tutmakta olan, devletin en üst yönetim organı Divân-1 Hümâyûn'un aldığı kararların kaydedildiği kaynaklara Mühimme Defterler denilir. Defterlerde yer aldığı şekli ile belgeler/bilgiler bu çalışmaya kaynaklık edecektir.

Mühimme defterleri, Osmanlı Devleti'nin birinci derecede önemli resmi kayıtlarıdır. Divan-1 Hümayûn'da alınan devletin önemli kararları bu defterlere yazılıdır. Bu kararlara hüküm denir. Padişahın payitahtta bulunduğu sırada, Sadrazam başkanlığındaki Divan toplantısından çıkan emirlerin kayıt edildiği defterlerdir. Eğer bu hükümler ilgilisine de gönderilecekse suretleri çıkartılarak ilgili vezirin bilgisi çerçevesinde ulak ile gönderilirdi. Genellikle gönderildiği kimseler, tebaadan ilgili bir kimse, beylerbeyi, hükümdar, hakim, kadı gibi önemli muhataplardır. Devletin özgün ve tartışmasız kayıtları olan bu defterler bu yönü ile o devirler ile ilgili hayatın her alanı ile alakalı değerli bilgi kaynaklarıdır. Günümüzde, gelişmiş ülkelere nitelikli nüfus aktarım aracı olarak değerlendirilen dış göçün Osmanlı Devleti’nde nasıl vuku bulduğu ilgi çekicidir. Bu sebeple özgün bir çalışma olması arzusuyla dışarıya göç ve dıştan göç konusunda devletin izlediği politika ne ve nasıl olmuş ve aynı zamanda hangi etkenler altında cereyan etmiş, sorularına cevap ararken bu kaynakların güvenilirliği, araştırmada Mühimme Defterleri'ni ana kaynak olarak incelemeye yöneltmiştir (Genç ve ark.., 2010, s.7).

\section{Osmanl Devleti’nde Nüfusa Bir Bakı̧}

Osmanlı Devleti'nde, üretimin büyük ölçüde tarıma bağlı olması ve nüfus-toprak oranının dengeli olmaması, yani nüfus yoğunluğunun düşüklüğü nedeniyle hem tahıl hem de vergi kaynağı olan üretimin optimum düzeyini korumak ve buna bağlı olarak herhangi bir şekilde nüfus kaybını önlemek ve korumak öncelikli politikalar arasında yer almaktaydı. Klasik dönemden itibaren en çok bilinen uygulamalar ve alınan tedbirler arasında çift bozan akçesi yer almaktadır (Arslan, 2001, s. 207-213).

Bulgular kısmında görüleceği gibi 16. yüzyıl başlarında bu nüfus hareketliliği daha çok mevsimlik göç niteliğindeydi. Göç edenler, Şah İsmail'in daveti üzerine onun seferlerine katılır, sefer sonrası geldikleri yerlere dönerdi. Daha II. Bâyezid döneminde durum böyleydi. Bu tür nüfus kayması doğal olarak Osmanlı tarım ve zenaat ekonomisine, dolayısıyla devlet gelirlerine zarar veriyordu (Djafar-Pour, 1977,s. 14-15). Nüfus kaybıyla birlikte tarımsal üretim duruyor ve bunun sonucunda kitlik ve yokluklara kadar olumsuz etkiler b1rakıyordu. Bu endişelerle II. Bâyezid, Şah İsmail'den seferlerini ve buna bağlı davetlerini ekim ve hasat mevsimleri dışındaki zamanlarda yapmasını istiyor 
ve tavsiye etmişti. Ama durumda düzelme olmayınca sonuçta sert önlemler alma gereği doğmuştu (Emecen ve Şahin,1994, s. XXIV). ${ }^{1}$

Osmanlı idaresi nüfus artışını tercih etmekte ve bu çerçevede ilgili merciler teşvik edilmektedir. Boş ve verimli topraklara nüfus aktarımı yanında, dıştan içe göç hareketleri de teşvik edilmektedir. Benzer şekilde, konar göçerlerin yerleşik hale getirilmesini hedefleyen iskan politikaları da, bir çok diğer amacın yanı sıra, öncelikle çeşitli sektörlerde üretim düzeyini arttırmak için de uygulama alanı bulmuştur. Tüm bunların yanı sıra, ülke yararına olabilecek her türlü bilgi ve nitelikli işgücü ile her türlü bilginin kaybına yol açmamak da bir başka neden olarak düşünülebilir. Bu tür bir politikanın altında yatan amacın; geniş kapsamlı olarak askeri, mali, ekonomik, sosyal ve siyasî politikaları gerçekleştirmek için daha fazla nüfusa olan ihtiyaçtan ortaya çıktığı kabul edilebilir. Tam aksi bir duruma, ülkenin çeşitli bölgelerinden içten dışa (sınır aşan) göçlere ise, bu göçlerin amacı ne olursa olsun müsamaha gösterilmezdi. Özellikle büyük kitleler halinde ortaya çıkan ve özünde devletle çelişik düştügünden çareyi dışa çıkmakta bulan nüfus hareketlerine, hem nüfus eksilişine yol açtığından hem de muhaliflere ve düşmana jeopolitik, stratejik, istihbarat ve lojistik destek yanında taze kuvvet olması ihtimali bakımından izin verilmek istenmezdi. ${ }^{2}$

Belgelerden izlenebileceği gibi bu tür nüfus hareketlerine karşı sosyal, idari ve ekonomik tedbirlerin etkili olmaması halinde, askeri ve caydırıcı tedbirlere de başvurulmuştur. Bu tedbirlere başvurmadan önce, öncelikle gerekli tedbirlerin alınması için ilgili ümera ve ehl-i örfe tavsiyede bulunulduğu görülmektedir. Bu tedbirlerin işe yaramaması durumunda, sert cezalara başvurulacağı fermanlarda özellikle vurgulanırdı. ${ }^{3}$

\section{Amaç}

$\mathrm{Bu}$ arşiv araştırmasının amacı; Osmanlı Devleti'nin, nüfus hareketleri kapsamında başka devletlerden kendisine göç eden ve kendi topraklarından başka devletlere göç edenlerin hangi etkenlerle yer değiştirdikleri hakkında bir fikir edinmektir. Asya ve Avrupa sınırlarında ve mücavir devletlerle bu kapsamdaki ilişkileri nasıl yönetmiştir. Nüfus çekme veya nüfus aktarma aracı olarak dış göç nasıl değerlendirilmiştir. Bu tür sorulara cevap aranırken 16. yüzyıla ait Mühimme Defterleri esas alınarak araştırma gerçekleştirildi. Belge örneklerin-

\footnotetext{
1 Bkz. aynı eserde geçen hükümler; Hüküm No: 47, evahir-i Zilkâde, Sene 906/10-16 Haziran 1501 Çarşamba; Hüküm No:71; evahir-i Z.ilkâde, Sene 906/10-16 Haziran 1501 Çarşamba. 2 Bkz. aynı eserde geçen hükümler; Hüküm No:453,454 evâhir-i Zilhicce 906/10-16 Temmuz 1501 Cuma.
} 
den yola çıkılarak bulgular değerlendirildi. Sonuçlardan esinlenerek günümüze dair projeksiyonda bulunmak da bu kapsamdadır.

\section{Yöntem}

Osmanlı Devleti' nin klasik dönem argümanlarına sıkı sıkıya bağlı olduğu dönem, 14-16. yüzyıllar olarak kabul edilir. 16. Yüzyıl Osmanlı Devleti'nin birçok yönden en gelişmiş asrı olması nedeniyle tercih edilmiştir. Konu makale boyutunda ele alınmıştır. Sınırlı sayıda orijinal arşiv belgesi ile yetinilmek zorunda kalınmasına karşın, çalışma ikincil kaynaklarla desteklenmiştir.

Osmanlıca Divani hattı ile yazılmış bulunan Mühimme hükümlerinin; transkripsiyonunu verildikten sonra, hükümden bağımsız olarak günümüz Türkçesi ile özeti ve ana teması verilmiştir. Konunun akışı içerisinde uygun olan yerlerde, anlaşılmasını kolaylaştırmak amacı ile hükümler sadeleştirilmiştir.

Konu; Osmanlı Devleti'nin Asya ve Avrupa kıtasındaki topraklarından örneklerle ele alınmıştır. Doğu ve batı sınırlarının birlikte ele alınma amacı; uygulamada birlik, bütünlük ve uyum ilkelerinin varlığı konusunda da bilgi edinebilmektir.

Mühimme Defterleri'ni kaynak gösterirken şu sıra izlendi: Mühimme Defteri numarası, sayfa numarası, hüküm numarası ve hükmün yazıldığı hicri tarih ve miladi karşılı̆̆ı verildi (Örneğin, Mühimme Defteri: 6, 206-207, 445. 26 Rebi'ü'l-evvel Sene 972/ 1.11.1564).

Girişten sonra amaç, yöntem, arşiv araştırması ve literatür taraması, bulgular, değerlendirme ve sonuç'un ardından kaynaklar listesi verilerek çalışma tamamlanmıştır.

\section{Arşiv ve Literatür Araştırması}

$\mathrm{Bu}$ çalışmanın belkemiğini Osmanlı Arşivi belge koleksiyonlarından biri olan Mühimme Defterleri oluşturmaktadır. Fert, toplum, devlet ve medeniyet olarak gelişmek, ilerlemek, nüfus yapısını ve niteliğini daha iyiye doğru geliştirmek adına bu tarihi geçmişten ve bu özgün kaynaktan yararlanarak bilimsel bir katkı sağlamak mümkündür. Bu düşünce ile 5, 6, 7, 12, 31, 32 ve 35 numaralı Mühimme Defterleri'nden Osmanlı Devleti'nin, doğu ve batı yakasındaki Asya ve Avrupa kıtalarındaki topraklarında dış göçe konu olabilecek nüfus hareketliliği konu edinilmiş ve birbiriyle ilgisi olan hükümler değerlendirilmiştir. Bu hükümlerdeki tarihi şahsiyetler, olaylar, mekanlar ve meseleler hakkında tamamlayıcı ve aydınlatıcı bilgileri ikincil kaynaklardan yararlanarak arz ettik. Eski okumalarımızdan yararlanarak aktardığımız bilgilere ise kaynak belirtme güçlüğü nedeniyle, ayrıca kaynak gösterilmemiştir. 


\section{Bulgular}

\section{Doğu Sinırlarında: İcten Dışa Göçün Önlenmesi}

Osmanlı Devleti'nin Asya topraklarında, doğu sınırları diye niteleyebileceğimiz alanlarda 1500 yılından itibaren Şah İsmail tarafından Safevî Türkmen devleti oluşturulmuştu. Bu başlık altında Van, Soran, Urmiye, İmadiye, Kazvin, Loristan, Mekri, Şehr-i Zol, Tebriz gibi yerlerde vuku bulan ve diş göç kapsamında değerlendirilebilecek nüfus hareketliliğini ele alacağız.

\section{Nüfus Hareketliliği: Mevsimlik ve Siyasi Göç}

Osmanlı topraklarından doğuya doğru hareketlilik Şah İsmail'in ortaya çıkışı ve öncesinden gözlemlenmeye başlamıştır. Mürit ve danışmanlarının tavsiyesine uyan İsmail, Erzincan civarındaki Sarukaya yaylağına giderken Anadolu’daki Sâfevi bağlılarını kendisine katılmaya çağırdı. Anadolu’nun köylü ve göçebe Türkmenleri, büyük bir istekle bu davete uyarak, asker ve idareci olarak Sâfevi Devleti'nin kurulmasında ve yükselmesinde büyük ölçüde etkili oldular (Djafar-Pour,1977, s.14). İşte Sâfevi Devleti'nin başlıca dayanağı olan bu Kızılbaş uluslarından Ustaclu (Usta-Hacıoglu, Ustaclu) lar, Sivas, Amasya bölgesinden, Rumlu'lar; Tokat, Amasya, Corum, Koyulhisar, Bayburt ve İspir köylülerinden; Tekelüler, Teke (Antalya) ve Menteşe (Muğla) sancağından; Zulkadirlu'lar, Maraş, Elbistandan, Yozgat bölgesindeki Dulkadir ulusundan; Şamlu'lar, Sivas-Uzun Yayla’da yaylayıp Haleb bölgesinde kışlayan Beğdili, Harbendelü, İnallu... Türkmenlerinden, Afşar'lar, Dulkadir ve Haleb Türkmenleriyle Akkoyunlu Afşarlarından ortaya çıkmış; Kaçar'lar XV. asır sonlarında, Bozok (Yozgat)'tan Azerbaycan'a göç edip yerleşmişlerdir. Yine ikinci derecede önemli Kızılbaş ${ }^{4}$ uluslarından Varsak'lar, Adana, Tarsus bölgesinden; Çepni'ler, Trabzon- Samsun'dan; Cerid'ler, Dulkadir-eli'nden; Turgud'lular, Konya bölgesinden gitmişlerdi (Djafar-Pour, 1977, s.15).

Belirtildiği üzere 16. yüzyıl başlarında bu gidişler daha çok mevsimlik göç niteliğindeydi. Gidenler Şah İsmailin daveti üzerine onun seferlerine katılır,

\footnotetext{
4 Başta Sünni-Şafi'i olan Sâfevî tarikatı;Şeyh Sâfînin torunu Hoca Ali’ den (1392-1422) itibaren tekkeye üşüşen Alevî Türkmenlerin etkisiyle Şiiliğe eğilim göstermiştir. Timur; Ankara savaşından sonra Anadolu'dan götürmekte olduğu esirleri, Hoca Ali'nin arzusu üzerine serbest bırakır. Hoca Ali, bunları azat eder. Bir kısmı, vatanlarına dönüp Teke-ili'nde (Antalya -Burdur yörelerinde) Safevî sevgisini yaydıkları, diğerlerinin ise Erdebil'e yerleşip "Rumlu” = Anadolu'lu adıyla şeyhin kabilesini ve bağlılarını oluşturduğu ifade edilmiştir. Bağlılarının çoğalması Şeyh Cüneyd'i (1447-1460), tarikatını dini-siyasi bir yapıya dönüştürmeye yöneltir. Ondan sonra oğlu Haydar, dayısı Uzun Hasan'a damat olup Erdebil'de tarikat postuna oturtulur. Savaşa hazırladığı müritlerini diğer askerlerden ayırt etmek için on iki imamı ifade eden on iki dilimli kırmızı renkli "Tâc" giydirerek surh-ser = Kızılbaş diye nitelenmelerine yol açar. Oğlu İsmail, Akkoyunlu'nun içinde bulunduğu karışıklıktan istifadeyle hicri 905/m 1500’de ayaklanır (Ali Djafar-Pour, 2010).
} 
sefer sonrası geldikleri yerlere dönerdi. Bu tür nüfus kayması, Osmanlı tarım ve zanaat ekonomisine ve bunların sonucu olarak devlet gelirlerine zarar veriyordu (Küpeli,2010, s. 228-230).

Aşağıdaki hükümde ise mezhep birliği sebebiyle Çepnilerin, Safevîlere destek sağlamayı amaçlayan nüfus hareketliliği söz konusudur;

Trabzon beyi Süleyman Beye Hüküm ki mektub gönderüb sancağında olan Kürtün ${ }^{5}$ kazasının re'ayası Çepni ${ }^{6}$ olub kızılbaş ahali olmağla bu def'a sulhdan sonra otuz nefer kimesne göç edüb öte canibe gidüb ve anlardan gayrı dahi ba’zı kimesneler yukaru canibe muttasıl nüzur cem' edüb varub gelüb haklarından gelinmezse cümlesinin geçmesi mukarrerdir, deyü bildirmişsin. İmdi melàin-i hasirinin haklarından gelinmek ehemm-i mühimmattandır. Buyurdum ki hükm-i refi'im varıcak bu babda tamam-1 basiret üzere olub bu hususı kimesne gadr etmeyüb ve kızılbaş teftiş olunur deyü şayi’ olunub anun gibi yukaru canib ile alaka eden kimesneler birer bahane ile ele getürüb dahi! şer'le teftiş edüb rafz ve ilhadı sabit ve zahir olundıysa habs edüb yarar adamlarla südde-i se'adetime gönderüb yazub bildirüb amma bu bahane ile kendü hallerinde olan kimselere zarar verdirmeyesin... (Mühimme; 5, 513, 1401. 17 Ramazan Sene 993 / 12.9.1585 Perşembe).

Trabzon Beyi'ne gönderilen yukarıdaki hükümde; Kürtün kazası'ndan 30 nefer kızılbaş Çepni'nin barış anlaşmasından sonra İran’a göç ettikleri, bunların dışında başkalarının da sürekli nüzûr ${ }^{7}$ topladıkları, bunların haklarından gelinmemesi durumunda tamamen göç edebileceklerinden bahisle tedbir alınması ve gerekirse haklarından gelinmesi, rafızi ve mülhid olanların yakalanarak İstanbul'a gönderilmesi ancak bu bahane ile kendi halinde olan kimselere ilişilmemesi emredilmiştir. Burada siyasî-mezhebî tercihe dayalı bir dış göç söz konusudur. Osmanlı Devleti, bu göçü birçok yönden uygun bulmamaktadır. Öncelikle siyasi yönden Safevîlere nüfus ve nüfuz yönü ile destek sağladığından izin vermemektedir. Olay mahallinde toplum huzurunu bozduğundan ve propaganda yöntemleri ile din ve inanç yönüyle insanları Osmanlı'nın arzu etmediği boyutlarda etkilediğinden uygun bulmamaktadır.

Aşağıdaki belgede ve zaman diliminde ise bu mesele daha da gelişmiş ve farklı boyutlar kazanmıştır;

\footnotetext{
5 Kürtün şimdilerde Gümüşhane'nin bir ilçesidir.

6 Çepni: Oğuz boylarından olup Üç-Oklar'dan Gök Han'ın dördüncü oğludur. İç Oğuzlar da denilir. Sol kolu teşkil ederler. Gök-Alp/Gök Han: Sembolü Sungur'dur. Bozulus aşiretlerindendir. "Düşmanı nerede görse savaşan, hemen çarpan, vuran ve hızlı savaşan" anlamına gelir. Türkiye, Suriye ve Irak’ta bulunurlar (Sümer, 1998, s. 269-270) ve (Kaya, 2011).

7 Nüzûr: Arapça çoğul bir sözcük olup tekili nezir-nazr'dır. Adak anlamına gelir (Sami, 2004, s. 1456). Ancak metinde Şeyh Cüneyd'in tekkesine gönderilen hediyelere verilen isimdir (y.n.).
} 


\section{İmadiye'den Urmiye, Tebriz ve Kazvin'e Firar Edenler}

07 N (Ramazan) 985 (/ 18.11.1577) tarihinde; Soran Sancağ beyine gönderilen hükümde, Van beylerbeyisi Hüsrev'in, dergâh-1 mu'llama, mektub gönderip, İmadiye Hakimi Kubâd Bey'in, karındaşı olan Behrâm adl1, kötü bahtlı, özünde mevcut olan ihanetini açı̆̆a vurup ilhâdı, ihtiyar etmekle ve kırk nefer miktarı adamı ile kayıplara karışıp sancağından geçip Kızılbaş’a ait olan Urmî(ye) adlı kasaba'ya varıp oradan kalkıp Tebriz'e varıp oradan Kazvin'e gittiğini bildirdiğinden (dolayı), imdi adı geçen hain senin sancağından geçip, gidip ve haini mukayyet olmamana sebep nedir? Adı geçen müfsidin işaret edilen karındaşı ile araları sulh üzere olmayıp südde-i sa'adetimden ${ }^{8}$ tayin olunan sancağ kendisine verilen yerleri kabul etmeyerek sürekli fitne ve fesâd, kavga ve husumette olduğu açık ve aleni olup [bu hallerinden anlaşlıyordu ki] elbette bir fesada başlayacağı ve sebep olacağı ma'lumum idi. Onun gibi adı geçen müfsit ita’ at dairesinden çıkıp da başka yere gitmek için sancağına uğradıkta dergah-1 sảadet-destgahıma olan ubudiyet ve ihtisasın mucebince yol vermeyip, üzerine varıp ölü veya diri ele geçirilmesi için ikdâm ve ihtimam etmen gerek idi... Onun gibi Memâlik-i Mahrusa'm halkından kimse yukaru canibe [İran'a] gitmek sevdasıyla senin sancağından geçip gitmek isterler ise yol vermeyip üstelik o asilerin atlarını ve sair soygunlarını ele geçirenlere ait olmak üzere mecâl vermeyerek üzerine varıp hangi yolla mümkün ise ele getirip hakkından gelmek bâbında ikdam ve ihtimam eyleyesin..." (Mühimme; 32, 20, 72.7 Ramazan Sene 985/ 18.11.1577).

Bir sureti Zor Sancağı Beyine, Bir sureti Brados Sancağı Beyine ve ismi okunamayan iki sancak beyine (Mühimme; 32, 20, 72 . 7 Ramazan Sene 985/ 18.11.1577) daha gönderilmiş olan bu hükümde; kardeşi ile arasında vaki anlaşmazlığın yanı sıra Osmanlı idaresince kendisine verilen sancağı beğenmeyip kırk adamı ile birlikte Van Vilâyeti'nden geçip İran'a ait olan Urmiye, Tebriz, Kazvin gibi yerlere uğradığı, fesât olarak bilinen işlerde bulunmaktan boş durmadığı ve ilhâdı yani dinden çıkmayı tercih ettiği ifade edilen 'İmâdiye Hâkimi Kubâd Bey’in kardeşi Behrâm’ın bu tavrı Rafıziliği tercih ve Kızılbaş tarafına geçmek olarak değerlendirilmiştir.

Hükme muhatap olan Van Beylerbeyi idaresindeki topraklardan geçip gitmesine göz yumduğu için eleştirildiği gibi adı geçeni ve beraberindekileri ölü veya diri ele geçirmesi emredilmekteydi. Bu tür geçişlere izin vermemesi ve İran'a gitmek isteyen asileri, eşya ve atları (ele geçirecek kimselere) ganimet olmak üzere ölü veya diri ele geçirilmesi emredilmiştir. Bu dönemde Osman11-İran ilişkilerine göz atıldığında, bu keskin tavrın sebebi anlaşılmış olur.

\footnotetext{
8 Südde-i Sa’adet: Mutluluk kaynağı eşik. Başkent İstanbul için kullanılan sıfat isim (y.n.).
} 


\section{Şah Tahmasb ve Safevîlerle İlişkiler}

Osmanlı hükümeti, Safevî hanedanı yönetimindeki İran'da Şah Tahmasb'ın ölümünün ardından gelişen olayları büyük bir dikkatle izler. Serhâd Beylerbeyilerine gönderilen hükümlerde: kalelerin ve askerin techizat ve teslihâtının ikmali, Sâfevî idaresi tarafından sulha riayet olunursa bu taraftan da ahid-nâmeye aykırı herhangi bir hususa izin verilmemesi, Sâfevî ülkesindeki karışıklığa rağmen tüccarların Osmanlıya gelişine müsaade olunursa Osmanlı ülkesinden de Sâfevî ülkesine ve Osmanlı tüccarlarının sınırı geçip yukarı tarafa gitmesine izin verilmesi, istenir. Eğer sınırlar kapatılıp tüccarlar bırakılmiyorsa bu taraftan da gitmek isteyenler birakılmayıp hareketlerini bir süre ertelemeleri emredilir. Ayrıca Sâfevî ülkesinin içinde bulunduğu şartların gözlenip araştırılması emredilmiştir (Uzunçarşılı, 1973, s. 55).

Sâfevîlerin 1555 tarihli Amasya anlaşmasına aykırı olarak; Gilân'dan, Osmanlı ülkesine gelmekte olan bir Osmanlı kervanı, Zengân'da (Sultaniye'nin kuzey batısında bulunan Zencan olmalıdır) basılarak malları yağmalanır ve tacirlerden çoğu öldürülürüp bir kısmı esir edilir. Bunun üzerine "Mabeynde sulh u salah emri muhakkak iken ve âyîn-i küffârda dahi kervan ve tüccara dahl $\mathrm{u}$ taarruz olunmak yoğ iken ahd $\mathrm{u}$ aman içinde böyle vaz' olunmanın aslı nedir?” diye Sâfevî idaresi'ne sorulur. Gönderilen iki çavuşa; gerekli cevap verilmemiş ve çavuşlar hapsedilmişti. Akıbetlerinin ne olduğunu öğrenmek için Van'dan gönderilen adamlar da tutuklanmıştı. 985/1577 yılı Şaban ayından itibaren Osmanlı merkezî hükümetini endişeye düşüren bu olayların ortaya çıkmasından sonra doğrudan doğruya Sâfevî hükümdarının etkisi ve teşvikiyle bu gelişmeler oluyor diye, Osmanlı tarafından algılanır olmuştu (Uzunçarş1l, 1973, s. 56).

Safevî yönetiminden anlaşmaya uygun olarak firar eden Behram ve adamlarının teslim edilmesi, Osmanlıya sığınanlara engel olunmaması isteniyordu. Yukarı canib diye belirtilen Sâfevî idaresinden, Şah II. İsmail'in babasından kalan barışı bozması üzerine Osmanlı Hükümeti, yalnız savunma ve ihtiyati tedbirler almakla yetinmeyip misliyle karşılık verme hakkını kullanarak Sâfevî ülkesinden, bu tarafa bağlılık gösterip gelmek isteyenlerin teşvik edilmesi, gelenlerin hallerine göre gözetilip riayet olunması için Osmanlı yönetimine yeterli ve gerekli bilgileri arz etmelerini, sınır beylerbeylerine emreder (Uzunçarşılı, 1973, s. 55-88).

Safevîler, bu dönemde geçerli olan barışı ihlal edip Osmanlı Devleti'ni kendisini savunmaya yöneltmiştir. Bunun fiili bir düşmanlığa dönüşmesi Şah'ın ölümünün duyulması üzerine gerçekleşmiştir. 20 Şevval 985 (2 Ocak 1578) tarihinde, doğu sınırları beylerbeyilerine 13 Ramazan günü vefat eden Şah II. İsmail'in hükümranlığı sırasında babası ile yapılan barış anlaşmasına bağlı kalmadığı, bundan başka "rafzı ihtiyar edüp, Yukarı Canibe iltica eden 
Ekrâd beylerine "külli riâyet" edip bazılarına "sancak tarikiyle" ülkeler vererek ahdi bozduğundan" durum gerçekten böyle ise, yeni hükümet kurulmadan önce Sâfevî idaresinden, ele geçirilmesi mümkün olan yerlerin zapt edilmesi ama bu bahane ile savaşmayanlara ilişilmemesi önemle belirtilmiştir (Uzunçarşı1l, 1973, s. 61-64)

Bir başka belgede ise;

\section{Şehr-i Zol'da Zulüm ve Baskıdan Dolayı Yurtlarını Terk Eden Ahalinin Durumu}

13 Ş. sene [986]/15.10.1578'de Şehr-i Zol Beylerbeyisi'ne hitab eden hüküm'de; Mektub gönderip Şehr-i Zol'a tâbi' Mekri Sancağı Beyi olan Mustafa, mektup gönderip sancağı ile sınırdaş olup Yukarı Cânib’e tâbi' olan Şeyh Haydaroğlu Kara Bey Sancağı yakınında Lih (?) adlı mevzi'de topraktan bir kale ihdas edip daima adamlar gelip livâ-i mezburun re'âyâsını göçürmek ile on pare karyeler haraba müteveccih olup daima fitne ve fesaddan yana boş durmamaktadır, diye bilgi verdiğinden, bildirdiğin sebepten dolayı buyurdum ki vardıkda te'hir etmeyip sen kendi canibinden mezbur Kara Bege mektup ve adam gönderüp mâbeynde olan sulha muhalif kale ihdas olunup ve adam göçürülüp karyelerin harap olmasına sebep olmak münasib nesne degildir. Tarafeynden şerầit-i emn u emana ri'ayet olunmak lazımdır diye vech u münâsib olduğı üzere haber gönderip kaldırılmasına gayret eyleyesin. Amma re'aya yurdlarını bırakıp o tarafa gittiklerinden asude hal olmayub zulüm ve te'addiden firar etmek [nasil kabul] olunur, bir ferde zulüm olunmasına rızâ-yı şerifim yoktur. Ümeraya tenbih eyleyesin (Mühimme; 31, 388, 863.Fi 13 Şaban Sene [986]/ 15.10.1578).

buyurulmaktadır.

Bu belgede Osmanlı Devleti ile Sâfevî idaresi arasında bir barış anlaşmasının bu tarihte geçerli olduğu vurgulanarak Sâfevî idaresi tarafında yer alan Şeyh Haydaroğlu Kara Bey'in buna aykırı davranarak Osmanlı'ya bağlı köylerden nüfus çektiği, dolayısı ile dış göçe yol açtığı anlaşılmaktadır. Ancak Osmanlı rêayâsının İran tarafına göçmesinin zulüm ve haksızlık eseri olduğu ifade edilerek buna padişahın rızasının olmadığı belirtilmektedir. Buna bağlı olarak Şehr-i Zol Beylerbeyine; re’âyầya zulüm ve haksızlık etmemeleri yönünde uyarıda bulunması emredilmiştir. Bu tarihte Osmanlı Devleti'nde tahtta III. Murad (h 982-1003/ m 1574-1595) bulunmaktadır. Sözü edilen sulh ve barış anlaşmasının Kanuni Sultan Süleyman (926-974/1520-1566) döneminde gerçekleştirilen Amasya (1555) anlaşmasıdır. Kaynakların belirttiğine göre Amasya muâhedesi'nin gerçekleşmesine kadar (8 Receb 962/ 29 
Mayıs 1555) Sâfevî idaresi ile herhangi bir anlaşmaya bağlı olarak uzlaşmaya girişilmemiştir (Uzunçarşıll,1973, s.65-68).

Yukarıda vurgulanan dış göçün ekonomik ve güvenlik etkenlerine bağlı olarak gerçekleşmiş olduğu ama devletin bunu uygun bulmadığı anlaşılmaktadır. Buna yol açanların sorgulanması üst yönetici olan beylerbeyinden talep edilmiştir.

\section{Ekonomik ve İdari Uygulamaların Etkisi: Aşiret Göçleri}

Bir başka belgede ise dışarıya göç eden, Osmanlı sınırlarını aşarak daha güvenli, huzurlu ve yaşanabilir yerler arayışında bulunan aşiretlerin ülke içi ve sınır aşan yer değiştirmelerinden söz edilerek buna yol açan ekonomik, idari, sosyal ve siyasal sebeplerin ortadan kaldırılması, yönetim ve arazi dağıtımında gerekli adaletin sağlanması talep edilmiştir.

\section{Sivas, Erzurum, Diyarbekir, Zulkadirlu- Yukaru Canib Hattında Bo- zulus-Karausul Göçü}

Fi 29 Ra.[976] Vilâyet-i Erzurum muharriri Ömer Bey’e hüküm ki vilâyet-i Erzurum kadılarına hükm ki sen ki Ömer Beysin mektup gönderip Erzurum ve Ulus kâdılarına hükm-i hümayunum gönderilip Hazine-i 'Amire'min Diyarbekir cânibi defterdarı olan Ahmed mektup gönderip Diyarbekir'e tabi' olan havass-1 hümayun'dan Bozulus ${ }^{10}$ ve Karaulus halkı kethüdaları gelip kadimi yaylak ve yurdumuz olan olan yerlere sancakbeyleri hali ve harabe ve haric ez-defter diyerek timarlar ta'yinle arz ve beylerbeyiler başkasına verdiklerini arz etdüğümüzde yine bize verilüb Diyarbekir ve Van ve Erzurum ve Rum ve Zul'kadirlu beylerbeyilerine hükm-i hümayun verilmişken yine verilmeyüb yurdsuz kalmağla yukaru canibe perakende olmak mukarrerdir. Bundan màada avarız ve rüsum-1 örfiyeden gayrı Bozulus ve Karaulus külli mukata'a iken ol dahi zayi’ olub mal-1 miriye külli ğadr olmuşdur, diye arz olundukda niza' olunan mahaller kadimden karye ve mezra'a olmayub konageldükleri yaylak ve güzlükleri ve kadimi davarları mer'aları olub....ve beglerbegiler birer ara koyub haric ez-defter diye vermiş ise onun gibi mer'a ve gözlelere hükm edüb bana verilmiş karye ve mezr'adır, ma’mur ettim diye kimesneyi ta'allül etdirmeyesin. İnad edenleri arz eyleyesin deyü ferman olunub Ulus taifesi sahile gitmiş bulunub ve evvel-i baharda Karahisar mevzi’ine Ulus gelmezden mukaddem gitmiş bulunub sonra avdet edenlerinden Erzurum beylerbeyisi mektub gön-

\footnotetext{
9 Havass-1 Hümâyûn: Geliri Padişaha ait olan arazilerden has kategorisine giren yerler.

10 Bozulus aynı zamanda Ankara-Yozgat ve Hüdavendigar (Bursa) ve Karahisar-1 Sahip bölgelerinde yer adı olduğu gibi bu anılan bölgelerde yukarıda anılan ulusların-aşiretlerin iskan yerleri olması da kesinlik arz eden bir durumdur.
} 
derüb Tekman çeribaşısı ${ }^{11}$ elinden hükm-i hümayun varid olup şenlik olan yerde ...(?) diye ferman olunmuştur. Zikr olunan yaylaklar ekseri Tekman sancağında olmağla haric ez-defterden timar olan sipahilere tevzi' tezkeresi verilmeyüb tahrir olunan sayir vilâyetler defteri ile geldükte aslı üzerine arz eyleyesin deyü ferman olunduğı bildirmeğin buyurdum ki vusul buldukta Tekman nahiyesinde ma’mur olub ba’zı sipahilere timara verilen nahiyelerden ulus taifesi niza' ederlerse bu babda sabıka dahi hükm-ü hümayun gönderilmiştir. Ol şenle[na]n karyeleri kaldırmayıp ve Ulus taifesine dahi bir yer ta yin edüb onlara da tenbih eyleyesin ki bunların terekelerin çekinmeyip ta’addi etmeyeler (Mühimme; 7, 848, 2321. Fi 29 Rebi'ül-evvel Sene [976]/ 21.9.1568).

Bu belgede dikkat çeken önemli bir husus; Bozulus ve Karaulus diye isimlendirilen iki taifenin yaylak ve kışlakları arası seyir trafiğidir. Bu belgeden anlaşıldığına göre bunlar Diyarbekir taraflarından kalkıp Karahisar ${ }^{12}$ mevzii’ne gelip buradan sahile ulaşmaktadır. Söz konusu olan Karahisar neresi olabilir? Varılan sahil neresidir? diye düşünüldüğünde akla en yatkın olanı Erzurum ve Tekman'a yakın bir yer olan Şebin-karahisar olması en makul olanıdır. Yine sözü edilen sahilden maksadın da Karadeniz sahili olduğu anlaşılabilir. Afyon Karahisar ve bu bölgeye yakın olan Akdeniz veya şimdiki adıyla Ege Denizi olması coğrafi uzaklık itibariyle uzak bir ihtimaldir.

Boş ve harap, tapu kaydı yok diye yerlerinin sancakbeyleri tarafından başkalarına verildiğini dile getirerek oldukça geniş bir alanda; Diyarbekir, Van, Erzurum, Rum (Sivas) ve Zulkadirlu (Maraş)'da, yurtsuz kalan Bozulus ve Karaulus taifelerinin Sâfevî ülkesine dağılacağı hususu işlenip vilâyet ilgililerinden ve kâdılardan gerekli tedbirlerin alınması istenmektedir. Bunların Sâfevî ülkesine gitmesi halinde devlet gelirlerinde ciddi anlamda azalma olacağı vurgusu yapılmıştır.

Bu belgede adı geçen aşiretlerin yurtsuz kalma riski üzerinde durulmuştur. Bu sorunun çözüme kavuşturulması istenir. Daha önce, bunların kullandığ ileri sürülen ama tapu defterlerinde kaydı yok diye başkasına kullanıma ve yerleşime açılmış yerlerde bulunanlara dokunulmaması ama adı geçenlere boş olan başka yerlerin verilmesi emredilmiştir. Aynı zamanda bu ulusların da bu hükme itaat etmeleri vurgulanmıştır.

Bir başka belgede şöyle denilmektedir;

11 Çeribaşı: Komutan,baş, reis anlamlarında kullanılır (Sami, 2004, s. 510).

12 Karahisar ismiyle birçok yerleşim yeri bulunmaktadır. Ama burada coğrafi mesafeleri dikkate alırsak sözü edilen yerin Karahisar-1 Şarkî, diğer adıyla Şebinkarahisar olduğu anlaşılır. Tarihte bu dönemde Erzurum’a bağlı iken daha sonra Sivas ve bugün de Giresin iline bağlı bir ilçedir. Bu yer sakinlerinin büyük bir kısmı yine Kanunî döneminde bugünkü Kuzey Irak bölgesinden getirtilerek buraya iskan edilmiş olan Şebenkâre aşiretinden gelmektedir. 


\section{Çifte vergilendirme ve Haksız Kazanç Kaynağı Görülen Ulusların Göçü}

[Yev]m ül-hamis fi 26 Rebi'ü'l-evvel sene 972 Konstantiniyye... Kethüdaya verildi....fi 972. Diyarbekir beylerbeyisine hüküm ki haliya dergah-1 mu’allama mektub gönderüb havass-1 hümâyûn olan Ulus taifesinin cümle kethüdaları ve a’yanı sana gelip kadimi yaylağımız ve yurdumuz olan yerleri hali ve harabedir deyü sancakbegleri ba’zı re'aya taifesine timara arz vermekle beylerbegi berâtiyle timâr alub, gelüb şenledüb yaylağa mani' olub ve bundan gayri sancakbeyleri sancağımız toprağındadır toprağımızda yaylarsız deyü yaylak hakkı taleb edüb andan ma’ada kadimi yaylağımızı yüz elli ve iki yüz koyuna ahara satub ol ba’isden niçe cema’at naçar Kızılbaşa çıkub gidüb ve Kızılbaş dahi tekrar resm-i yaylak alur ve yaylaka gidüb gelince her sancakbeyi her sürüden birer koyunumuz ve her obadan birer keçe ve her haneden birer nögi yağ alub ziyade zulm ederler, şöyle ki kadimi yaylağımız inayet olunmaya ve sancakbeylerinin zulümleri def' olunmaya cümlemiz perakende olmak mukarrerdir deyü arz olunmasın taleb ve tazarru' edüb fi'l-vaki' mukaddema sen emr-i şerifimle Malazgird Beyi'nin teftişine vardığında, Ulusun kadimi yaylağı olan Malazgird ve bağlı yerlerin ve kırk ahur ve küsur ve Zerduman ve Belican ${ }^{13}$ nam yerleri ba'z1 ra’iyyet taifesi harabeden timar alub hidmete yarar kimesneler dahi olmayub ulus taifesi ol ecilden iki üç yıldan berü Kızılbaş vilâyetine varıp, yer resmi dahi Kızılbaş alduğı sahih mukarrer olub ve Kızılbaş tarafına giden ulus döndürmek murad eyledük yaylakları şenlik olmakla döndürmek müyesser olmadı ve'l-hasıl emr-i şerifle bir mu'temed kul gelüb ulus taifesinin ahvallerin teftiş edüb görüb harabeden timarlar alanlar men' olunub kadimi yaylakları alıverilüb ve sancakbegleri aldukları resm ref' olunub cânib-i miriden bir def'a resm-i yaylak alındıktan sonra ahardan tekrar alınmak ref' olunmaya Kızılbaşa gitmeleri mukarrerdir. Mal-ı miriye külli ğadr ve zarardır. Tedariki lazımdır, deyü arz eylemişsin. İmdi bundan akdem Erzurum Beylerbeyisi tarafından bu husus i'lam olundukta Malazgird kal'asının, Karayazı ve Hınıs'in ve etrafında ulus taifesinin kadimi davarları yürüyügeldiği yaylak ve mer'alarından haric ez-defter timar alanlar ref' olunması için mumâ-ileyh beglerbegine hükm-i şerif irsâl olunup gereği tenbih ve te'kid olmuş idi. Buyurdum ki hükm-i şerifim vardığında ulus taifesi Berriye ${ }^{14}$ canibinde olan kışlaklarından gelip yaylalarına çıkmalı oldukta, olduklarında bi'z-zat mevazi'-i mezkura varub ulus taifesinin kadimi davarları yürüyügeldügi mer'aları ve yaylakları ve sevadları ne mahaller ise ma'lum edinüb kadim ül-eyyâmdan mảmulün-bih olan sınırların ta’yin ve tebyin edüb

\footnotetext{
13 Van ile Hakkari arasında bir yer. Gevar (Berfican?) (Akbayar, 2001, s.20).

14 Berriye: Halen Şanlı Urfa'nın bir ilçesi olan Birecik, bazı belgelerde Berriyecik diye geçer (y.n.).
} 
sınırları dahilinde olan yaylak ve mer'a ve sevadlarından sonradan haric ez-defter diye ne mikdar tımara verilmiş yerleri var ise şenletip ma’mur edenleri ve şenletmeğe mübaşeret edenleri bil'külliye ref' edüb kadimi mer'a ve yaylakların kemâ-kân taife-i mezbureye mahsus kılub korudub sinurları dahilinde asla bir ferdi komayub men' ve def' edesin. Ol asıl yerlerin şenletmek yolu ile timar alanların cümlesinin beratların ellerinden alıp bir kiseye koyup mühürledikten sonra südde-i se'adetime irsal eyleyesin. Ve Berriye canibinden yaylaklarına varınca ve Berriye canibine inmelü olduklarında mürur etdükleri yerlerden beglerbegilığında vaki' olan sancakbeglerine ve voyvodalarına ve zü'ema ve erbab-1 timara ve ummal ve mübaşirîne toprağımızdan geçdiginuz otlak hakkı deyü ve sair bahane ile koyunlarına ve davarlarına dahl etdirmeyüb defter ve kanuna muhalif nesnelerin aldırmayub kendü canibinden yolları üzerinde olan sancakbeglerine ve kadılara mektub gönderüb gereği gibi yasağ etdürüb ve nasıl sancakdan ve kadılıkdan mürur ve ubur edegelmişler ise ol sancakların ve kadılıkların isimlerin yazub bildiresin ki taife-i mezbureye asla dahl olmamağ içün herbirine mü'ekked ve müşedded ahkam-1 şerife gönderilüb tenbih oluna ba'de ' $t$-tenbih eslemeyenlerin mansıbları ve dirlikleri alınmağla konulmayub bir vecihle haklarından geline ki işidenlere mucib-i ibret ve nasihat vaki ola ki taife-i mezbureye kimesne hilaf-1 şer' u kanun dahl etmege mecalleri kalmayub eyyam-1 adalet-hümayun ve hengam-1 se'adet makrunumda taife-i mezbure yaylaklarına ve kışlaklarına varub gelmelerinde müreffeh ül-hal olalar inşaallah ü'l-e'azz vakti ve mevsimi gelüb ol câniblere varduğunda yaylakların ve mer'aların ne vecihle ta'yin ve temyiz ve tedarik etdügın a'la t-tafsil yazıp südde-i se'adetime bildiresin. Bu emr-i şerifim üzere yaylakların ahvallerin görülüb ber-taraf olduğu ma'lum-1 şerifim ola, şöyle bilesin ${ }^{15}$ (Mühimme; 6, 206-207, 445. 26 Rebi'ül-evvel Sene 972/ 1.11.1564).

Sancakbeylerinin yasa dışı yollarla, el koyarak yaylaklarını başkasına tımara verdiğinden dolayı sınır ötesine (İran'a) göç eden uluslardan orada da çeşitli adlar altında vergiler alındığından bahisle çifte vergilendirmeye son verilmesi ve haksız yere yaylaklarından uzaklaştırılan ulusların, Osmanlı hudutları içerisine geri dönüşünün sağlanması, yaylaklarının iade edilerek yaylak ve kışlaklarına huzur içinde varıp dönmeleri temin edilerek hiçbir şekilde haksızlık yapılmaması hususunda gerekli bütün önlemlerin bir an önce alınarak adaletin sağlanması, zulüm ve haksızlığa yol açanların adalet üzere cezalandırılması ve bütün bunlara ilişkin tafsilatlı bir raporun padişah'a gönderilmesi hususlarını konu alan bu hükümler Diyarbekir ve Erzurum Beylerbeyilerine gönderilmiştir.

15 Aynı konuda 446. hüküm Erzurum Beylerbeyine yazılmıştır. 
Yukarıda verilen hükümde, dikkat çekici diğer bir konu bu ulusların bugünkü Urfa-Birecik-Diyarbakır-Erzurum-İran gibi geniş coğrafi alanlarda yaylak-kışlak hayatı yaşamalarıdır. Bu uluslar, yani aşiretler iki devlet ve yöresel idareciler için vergi ve gelir kaynă̆ı olarak görülmektedir.

\section{Duştan İçe Göçün Teşvik Edilmesi}

Doğu Sinırlarında: Luristan Hakimliğ ${ }^{16}$

Osmanlı idaresi tarafından Luristan Hakimi Muhammedi Mirza'ya yazılan mektuba göre; kendisine, Gazi Han’a verilen ülkelerden olmak üzere ailesi, bağlıları ve aşiretiyle birlikte iltica edip yerleşmesi için tahsis edilen araziden bahisle ve buna bağlı olarak kendisinden İslam dinini savunma konusunda, Osmanlı Devleti'nin düşmanlarını gözetlemede ve devleti korumada gerekli gayret ve çabayı göstermesi talep edilmiştir. Aşağıda vereceğimiz belgeden anlaşıldığına göre; bütün aşiret, aile ve bağlılarıyla Osmanlı sınırları içine gelmek isteyenlere Osmanlı idaresi yer ve imkân sağlayarak nüfus artışını gözetmektedir. Hedeflenen diğer konular arasında; güvenliğin sağlanması, söz konusu yerlerin şenlendirilip mamur hale getirilmesi, yani üretim ve vergi artışı sağlanarak ekonomiye ve sosyal hayatın geliştirilmesine katkı sağlanması gibi konular sayılabilir.

\section{İltica Eden Luristan Hakimi Muhammedi Mirza ve Bağlılarına Davet}

Cenab-1 emâret-me'âb, eyâlet-nisâb, devlet ittisâb, se'âdet iktisâb.... Muhammedi Mirzâ dâmet me'âlihi....sermâye-i devlet ve ikbal ve pirâye-i rıf'ât ve iclâl mülahazasıyla akvâm ve aşâir-i ve ehl u iyali iltica içün memalik-i mahrusa'ya irtihal eylemek tedarikinde olub...Gazi Han'a verilen ülkâlardan olunmak istid'a olunduğı iş̧âr olunmuş, imdi,...hala sancakları görülüb zât-1 firsat sıfatınıza erzâni kılınmak hususı...olunub ol-babda ...atebe-i ulya'dan berât-1 sa’adet ayât yazılub savb-1 ... irsal olunmuşdır. İnde'l-vusul nihad-ı mekremet mü'tadlerinde merkuz olan vüfur-1 fehm ve firâset ve kemâl-i akl u kiyâsetleri ve asitâne-i sa’adet-aşiyaneye olan hulus-1 taviyyetleri müsted'asınca oldur ki bu def'a emr-i celil ü’l-kadr... ittisal eyleyüb aşẩir ve ehl u iyaliniz ile ol canibden irtihal ve zikr olunan sancaklara intikal eyleyüb hıfz ve hiraset ve zabt ve siyanetde mucidd u merdane olub a'da tarafina nazır ve akvam $\mathrm{u}$ aşa'irunuz ile daima hazır bulunub ol etrafdan umur-1 din-i mübin ve uğur-1 hümâyun-1 devlet karin-i padişâhiye müte'allik hususlara bezl-i makdur ve sa'y-i nâ- mahsur olunub envầ yüz aklıkları tahsiline

16 Luristan: Batıdan Erak, Güneyden Huzistan, Kuzeyden Hersin ve Nihavend, Doğudan Rûdsezâr ile sınırlıdır. Bir ara 998h.de (1590) İstanbulda yapılan anlaşma ile Osmanlı yönetimine bağlandı. 1603'te tekrar Sâfevî İdaresine bağlandı. İran'ın Batı tarafında yer alır. Kürtlerin bir kolu olan Lurların yaşadığı bölgedir (Kurtuluş, 2003; Sami, 1996, s. 4013). 
mesâiyi cemile ve asâr-1 celileleri istid'a ile buyrulur (Mühimme; 32, 376-377, 668. 19 Rebi'üll-evvel Sene 986./27.05.1578 Pazartesi).

Osmanlı idaresi aynı gerekçelerle tam aksi bir strateji de izliyordu. Yine sınır boylarında güvenlik gerekçesi ile bu kez Osmanlı topraklarına girmek isteyen ve sınır boylarında asayiş sorunu ortaya çıkartma potansiyeli olan hareketleri engelliyordu.

\section{Yukarı Canib’ten Osmanlı Ülkelerine Ulusâtın Girişine İzin Verilme- mesi}

Yukarı canibden memalik-i mahrusa’ya gelen ulusât taifesinin fesâd ve şena'atte bulunmalarına mebni duhullerinin men'i hakkındaki emr serhad beylerine tenbih edilerek bu sene kimsenin içeri sokulmadığı hakkında Bağdad beylerbeyinin arzından bahisle... (Mühimme; 12, 42, 86. 23 Ramazan Sene 978/ 18.02.1571).

Yukarıda verilen belgede, Bağdat Beylerbeyine bağlı beylere gönderilen bir hükümde, fesat ve kötülüklerde bulunmak üzere Yukarı Cânib olarak adlandırılan İran yönünden, Osmanlı topraklarına giriş yapılmasını yasaklıyordu. Bu belgede, Osmanlı ülkesine gelmek isteyen ve ulusât olarak belirtilen aşiret ve grupların asayiş bozucu, fesat ve kötülük yapıcı olduklarından dolayı Osmanlı Ülkelerine girişlerinin önlenmesi konusunda sınır bölgesinde bulunan beyler uyarılarak, bu tür kimselerin sınırdan içeri sokulmaması üzerinde durulduğu anlaşılmaktadır.

Yukarıda verilen hükümde; İran'dan gelen aşiretler, asayişi bozduğundan (fesat ve kötülükler yaptıklarından) Osmanlı ülkesinin Bağdad Beylerbeyliği’ne bağlı sınırlardan, içeri sokulmadığı ifade edilmiştir. Bu belgede dikkat çekici bir başka durum ise ulus sözcügünün Arapça çoğul yapılarak ulusât= uluslar=aşiretler anlamında kullanılmış olmasıdır.

Bu belgede dikkatimizi çeken önemli bir husus dışarıdan göç alırken özen gösterildiği, kontrollü bir diştan göç alma siyasetinin takip edildiğidir. Çepnîlerle ilgili belgelerde göz önüne alınırsa fesat yapıcı, kötülük ve zarar verici nüfus hareketlerine çift yönlü olarak izin verilmediği anlaşılmaktadır.

\section{Batı Sınırlarında: Erdel Krallı̆̆ı}

Batı sınırları ile kastettiğimiz bölge Osmanlı Devleti'nin Avrupa kıtasındaki topraklarında yer alan sınır boylarıdır. Bu alana bugünkü Macaristan ve Avusturya gibi ülkeler girmektedir.

Aşağıda verilen belgede görüleceği gibi Osmanlı Devleti kendisine bağlı krallıklar ve vilayetler-eyaletler arasında yer değiştirmelere de sıcak bakmamış- 
tır. Bu belgede belirtilen temel endişe, yer değiştirmelerin re'âyanın sadakat ve samimi bağlılık hislerine zarar vereceği olarak gösterilmektedir.

\section{Ekonomik etkenlerle Erdel Krallığına Bağlı Yerlerde Yer Değiştirmeler}

Atlas kise ve gümüş kozalak ile Paşa hazretlerine, Yahya Çavuş ${ }^{17}$ ile gönderildi. Fi 25 S.sene m. [973] Erdel ${ }^{18}$ kralına nâme-i hümayun ki haliya sana tabi' olan Seyeş ve La'uş [Sebeş ve Lugoş ${ }^{19}$ hakimleri etraf ve cevânibine sid ve sada bırağub re'ayadan her kim gelüb bu yerlerde mütemekkin olur ise üç yıla degin mu'af ve müsellem olalar demekle memâlik-i mahrusamdan Vidin ve Feth ü'l-İslam ve Tuna etrafında olan kefere bu makule haber istimầ etmekle ekseri kalkub ol tarafa gitmek üzere olduğı istima’ olundı. İmdi zikr olunan hakimler eger bu makule vaz' edüb memâlik-i mahrusam re'âyası anda varub tavattun etmek atebe-i ulyama olan sadakat ve ihlas muktezası degildir. Gerekdir ki nâme-i hümayun'la dergah-1 mu'allam çavuşlarından Hasan zîde kadruhu vusul buldukta bu babda mukayyed olub anun gibi mezkurların bu vecihle fi'illeri olub memâlik-i mahrusam re'âyasından anda kimesne varmış ise tetebbu' edüb buldurasın. Asitane-i se'adetime olan vufûr-1 ihlas ve hüsn-rihtisâsın mucebince kangi yerden kalkmış ise gerü yerlerine gönderüb min ba’d mezkur hakimleri ol vecihle vaz' etdirmeyüb men' ve def' etmek babında enva'-1 mesầi-yi cemile zuhura getüresin ve bi'l-cümle memâlik-i mahurusam re'ayasından anda olub tavattun edenleri girü yerlerine avdet etdiresin (Mühimme; 5, 108, 252. 25 Safer Sene m.[973]/ 21.9.1565 Cuma).

Bu hükümden anlaşıldığı üzere 1565 yılında Erdel krallığı, Osmanlı Devleti'ne tabiidir. Sebeş ve Logoş hakimleri ise adı geçen krallı̆̆a tabiidir. Bunlar, duyuru yaparak ve çağrıda bulunarak; civarlarına yerleşmek isteyenlere üç yıla değin vergi muafiyeti tanıdıklarını yaymışlardır. Bununla hakimliklerin nüfusunu artırma amacını gütmektedirler. Bunu duyan Osmanlı Devleti teba'asından Vidin, Feth ü'l-İslam ve Tuna etrafında yerleşik Müslüman olmayan tebaanın çoğu kalkıp o taraflara gitmek üzeredir. Bir kısmının da gittiği anlaşılmaktadır. Yukarıda verilen hükümde kraldan bu yerlere göçmüş teba’ayı buldurması ve önceki yerlerine iâdesi istenmektedir. Ayrıca bu göçün Osmanlı Devletine sadakatla bağlı olmak ile bağdaşır bir davranış olmadığı ve göç edenler nereden gelmiş ise geldikleri yerlere geri gönderilmeleri emredilmiştir.

Erdel Kralı, nüfus çekme aracı olarak üç yıla değin vergi muafiyeti imkanı sağlamıştı. Osmanlı Devleti, bu uygulamayı kendi genel nüfus ve yönetim

7 Yazılan hüküm ve fermanları ilgilisine teslim etmekle görevli ulak (y.n.).

18 Başka adı Transilvanya (Akbayar, 2001, s. 52).

19 Şepeş-Lugoş Tamışvar'a bağlı yerler olarak gösterilir (Akbayar, 2001, s. 152). 
politikalarına uygun bulmamaktadır. Bu şekilde Osmanlı ülkeleri reayası olup yer değiştirenlerin tespit edilerek geri geldikleri yerlere yerleştirilmeleri emredilir. İsmi verilen yerlerin Hakimlerinden de böyle bir uygulamaya girişmemeleri istenir.

Bu göç, her ne kadar Osmanlı’ya tabi olan bir krallığa bağlı yerlerde geçmekte ise de Osmanlı Devleti'nin iç bölgelerinden nüfus çektiğinden ve direk etkisi altında olan alanlardan göç aldığından içten dişa göç olarak değerlendirmek mümkündür. Nitekim bu yer değiştirmeler sonucu vergi kaybının yanı sıra nüfus azalması endişesi de duyulmaktadır.

\section{Semendire, Alacahisar, İzvornik, Vidin ve Temeşvar'da Nüfus Hareket- liliği}

1567 tarihli şu hükümde de benzer bir durum söz konusudur: Semendire $^{20}$, Alacahisar, İzvornik ${ }^{21}$ ve Vidin'den harac ${ }^{22}$ toplamaya gidenler haracın noksan olduğunu görüp inceleyip araştırdıklarında Temaşvar vilâyetinde haraç, ispençe ve koyun hakkı hane başına yazılmış olup diğer yerlerde nüfus başına yazılmış olmakla o yerlerin re'ayasının Temeşvar vilâyetine hicret ettiklerini anlarlar. Buradan oraya adam geçirilmemesi, gidenlerin iadesi ve memleketin ma’mur olması amaçlanıyorsa Şebeş ve Lagos ve Macar'dan reaya getirmeğe çalışıp yoksa bir tarafı boşaltıp diğer tarafı doldurmakta bir yararın olmadığı ifade edilmiştir (Mühimme; 7, 170, 448.11 Cemaziye'l-evvel Sene 975/13.11.1567 Perşembe).

Belirtilen dört yerleşim yerinden haraç toplamaya gidenler haracın noksan olduğunu görüp incelediklerinde, Temaşvar vilâyetinde, hane başına bu belirtilen vergilerin defterlere yazıldığı, diğer yerlerde ise nüfus başına yazıldığından belirtilen yerlerdeki re'ayanın Temeşvar vilâyetine göç ettiklerini anlamakla buradan oraya adam geçirilmemesi, gidenlerin iadesi ve memleketin mamur ve bayındır olması isteniyor ise Şebeş ve Lagos ve Macar'dan Temaşvara ve buraya reaya getirilmeye çalışılması gerektiği uyarısında bulunulur. Bir taraftan nüfusu boşaltıp diğer tarafa aktarıp bu yeni yerdeki nüfus boşluğunu aktarılan nüfus ile doldurmakla bir fayda elde edilmeyeceğine dair ilgililere gösterilen hükümde içlerden nüfus çekilmesi yerine dıştan içe doğru bir nüfus akışının temin edilmesi istenmektedir.

16. Yüzyıl boyunca Macaristan'da merkezleri Buda (Budapeşte) ve Temeşvâr (Temeşvar veya Tımışvar okunuşları vardır) şehirleri olmak üzere iki beylerbeylik varlıklarını kesintisiz olarak sürdürebilmişlerdir. Her ikisine de pek çok sancak bağlıydı. Feth edilen bölgelerle sayıları giderek artmış, daha sonra-

20 Budin'de sancak adı (Akbayar, 2001, s. 84).

21 Budin'de sancak adı. Aynı zamanda Bosna'da Tuzla-i Zir olan sancak (Akbayar, 2001, s. 84).

22 Harac: Gayr-1 Müslim tebaadan alınan vergi (y.n.). 
ları ise başka sebeplerden dolayı bir miktarı azalmıştır. Stratejik durumu, tarihi geçmişi ve topraklarının genişliği nedeniyle Buda Beylerbeyliği hep daha ünlü ve itibarlı bir konumdaydı.1560'lı yıllarda bu vilâyete yirmi beş sancak (liva-il) bağlıydı (Geza, 1999, s. 20-121).

\section{Batı Sinırlarında: Segedin Sancağ $\imath^{23}$}

Aşağıda verilen hükümde ise kâdı, naib, voyvoda, zâim, sipahi ve diğer görevliler tarafından zulme ve baskıya maruz kalan halkın çoğunun vatanını terk ederek dar ü’l-harb olan yere (Macaristan’a) sığındıkları bilgisinin halk tarafından bildirildiği, bundan dolayı adı geçen İshak Bey’in kınandığı belirtilir:

\section{Segedin Beyi’ne ve Yöneticilere Vatanını Terk Edenlerle İlgili Adalet Çă̆risı}

Segedin beyi İshak Beye hüküm; Segedin beyi İshak, kadı, naib, voyvoda, zaim, sipahi ve saire tarafından zulüm ve te'addi edilmesinden dolayı halkın ekserisi terk-i vatanla dar ül-harbe (Osmanlı ile barışık olmayan yurtlara) iltica ettiği ahali tarafından bildirildiğinden itaba müstehak olduğu, gelecekte zulüm ve haksızlığa meydan vermeyip livanın gereği gibi şenlenip mamur olmasına çalışması, aksi halde azil edilmekten başka acı bir şekilde kınanacağı vurgulanan hükmün suretleri Peçoy, Sekçoy, Kuban, İstolni, Şemontorne, Seksar, Filek, Seçen, Novigrad, Solnuk, Sirem, Pojega, İzvornik, Estergon, Hatvan, Semendire, Arad,...beylerine gönderilmiştir ${ }^{24}$ (Mühimme; 35, 262, 664. 27 Receb Sene 986/ 10.10.1577 Perşembe).

$\mathrm{Bu}$ belgeden de anlaşıldığı üzere nüfusun; zulüm, haksızlık, baskı gibi adalete aykırı sebeplerden dolayı ülke sınırları dışına çıkması uygun görülmemiştir. Adı geçen vilayetin gelişmesi arzu ediliyorsa bunun aksi bir nüfus politikası izlenerek, dışardan nüfusun bu vilayete göç ettirilerek yerleştirilmesi ve çekilmesi çerçevesinde politikaların izlenmesi üzerinde durulmuş ve emir niteliğinde önerilmiştir.

\section{Değerlendirme ve Sonuç}

Çalışmada yararlanılan ve değerlendirilen Mühimme Defterleri'nden ve kayıtlarından; 16. yüzyıl sonlarında doğuda İran ve batıda ise Macaristan-Avusturya sınır bölgelerinde, Osmanlı tebaası ve reayası olan nüfusun ülkeden dışarıya göçlerine ilişkin olarak, merkezi yönetim tarafından, bu tür nüfus hareketlerinin sakıncaları belirtilerek engellenmesi amacıyla gerekli tedbirlerin

\footnotetext{
23 Budin Eyaletinde diğer adı Eğri (Baçka, Szeged) olan sancak (Akbayar, 2001, s. 142).

24 Hükmün orijinalinde isimleri zikredilmiştir.
} 
acil olarak alınmasının talep edildiği anlaşılmaktadır. Tedbir olarak haksızlığın giderilmesi, zulüm ve baskı uygulayanların cezalandırılması ve adaletle hükmedilmesi vurgusu yapılmıştır.

Bu belgeler ışığında; güvenlik arayışı, yaylak ve kışlak yerlerinin farklı gerekçeler ileri sürülerek idareciler tarafından ellerinden alınıp başkalarına verilmesi, vergi yükünün ağır gelmesi, Osmanlı Devleti'nin yer ve imkân sağlayarak iltica edenleri davet ve teşvik etmesi, Doğu sınırlarında sancak olarak Behram Beye verilen yerlerin bu zat tarafindan yeterli bulunmaması, Çepnilerin mezhep birliği sebebiyle Safevîlere katılma düşüncesiyle hareket etmeleri, Batı sınırlarında üç yıla kadar vergi muafiyeti imkanı sağlanarak içten nüfus çekilmesi, gibi sebeplere dayalı dış göç hareketleri görülmektedir.

Osmanlı yönetimi; yöneticilerin haksız uygulamalarının, zulüm ve baskılarının önünün alınması üzerinde özellikle durur. Ülkelerinin gelişmesine, vergi gelirlerinin düşmemesine ve özellikle yükseltilmesine özen gösterdiği, insanların ve sınırların güvenliğinin sağlanmasına önem verdiği için buna yol açan sebeplerin ortadan kaldırılmasını ilgili yöneticilere hükümler ile iletir.

Bu belgeler dikkate alındığında; üretim, güvenlik, imar, huzur ve refahın gelişmesine katkı sağlamak amacı ile Osmanlı Devleti'ni doğuda ve batıda sınır komşusu olan ülkelerden, dıştan içe doğru bir göçü devletin dış nüfus politikası olarak tercih ettiği görülmektedir. Dıştan içe nüfus çekme aynı zamanda ülkenin ilgili bölgelerinin insan ile şenlendirilmesi, canlandırılması, imar edilmesi, ekonomik ve mali yönden değerlerin üretilmesi bakımından devlet tarafından önemsenmiştir. İçten dışa nüfus göçmesini de bu anlayışın yanı sıra rakip devletleri ekonomik, askeri, siyasi, idari ve güvenlik ve insan kaynağı açısından güçlendireceğinden uygun görülmemiştir. Ayrıca ekonomik, sosyal ve siyasal yönden iç huzuru bozduğu için içten dişa göçün önlenmesi konusunda adalet üzere gerekli önlemlerin alınmasını önemle belirtmiştir.

Nüfus hareketliliğine konu olan iç-dış göçmelerinin; kiminin mevsimlik sınır aşan göçler olduğu, kiminin taraflar arası anlaşmazlıktan ve idarecilerin uygulamalarının sebep olduğu memnuniyetsizlikten kaynaklandığı anlaşılmaktadır. İnsan unsurunun ve nüfusun bir devletin varlığını sürdürmesi için temel ve vaz geçilmez olduğu görülmektedir. Bir devletin dışardan nüfus çekme ya da ülkesinde var olan nüfusu koruyabilmesi için olduğu kadar ülkenin refah ve gelişmesini sağlayabilmesi için de bu insan unsurunu ve nüfus kütlelerini başta güvenlik, ekonomik, politik, idari, hukuk ve adalet noktalarından olduğu kadar yaşadıkları alanlarının kendilerine yeterliliği ve uygunluğu bakımından da tatmin etmesi gerekir.

Dış ekonomi politikası kapsamında; kendine yeterliliği sağlamak amacı ile ekonomik kaynakların ithalatını serbest bırakma, buna karşın silah, binek, erzak, mühimmat ve benzeri savunma ve hayatî değeri olan belirli maddelerin 
ihracatını sınırlandırma, izne tabi kılma veya tamamen yasaklama politikasını (Genç, 2013) takip ettiği gibi nüfus politikası olarak bununla senkronize bir şekilde içerden dişarıya nüfus göçmesine izin vermediği ama dıştan içe nüfus çekmeyi, kontrollü ve tercihli bir yöntemle teşvik ettiği görülmektedir.

Bir ülkenin gelişmesi ve her yönü ile büyümesi nüfus ve ekonomik kaynakların yeterliliğine dayalı olduğuna göre bugün de insan hak ve özgürlükleri engellenmeksizin, nüfusun bulunduğu yerde yaşamasını teşvik ederek ve refah şartlarını sağlayarak ülkede kalmasının sağlanması yönünde nüfus politikalarının uygulanması önerilir. Bugün az gelişmiş ülkelerin beyin göçü diye nitelenen nitelikli insan unsurunun gelişmiş ülkelere göçmesi ile göç veren ülkelerde fert ve toplumun entelektüel, bilimsel ve hayatı alg1 düzeyi düşmektedir. Buna karşın göç alan ülke sosyolojik, ekonomik, askeri, stratejik ve benzeri birçok yönden avantajlı duruma yükselmektedir. Bunun sonucu olarak göç veren ülkelerin yarı veya tam sömürge haline getirilmesi, bağımlı ülke konumuna düşürülmesi söz konusu olabilmektedir. 
Arslan, H. ve Özbay, R. D. (2015). [Extended Abstract] Emigration in the Ottoman state due to economic and political factors: in the muhimmah books in the 16th century. Turkish Journal of Sociology, 2015/1, 3/30, 397-424.

\title{
EXTENDED ABSTRACT
}

\section{Emigration in the Ottoman State due to Economic and Political Factors: In the Muhimmah Books in the 16th Century}

\author{
Hüseyin Arslan*, Rahmi Deniz Özbay ${ }^{* *}$
}

Immigration is the incident of geographical movement of a person or people from one location to another in order to spend their future life partly or completely so that they can settle there for good or temporarily. Migration, which is a type of social movement, can be studied as immigration and emigration. "The population movement that occurs by getting across the borders of a country in both the directions with a view to working, settling is called emigration (external migration). Meanwhile, seasonal migration is that type of migration whereby a person/people leave their place except in those times when the economic activities in that place from which they emigrate are busy until the next time in order to work in other regions.

Those references wherein those decisions taken by Divan Al-Humayun (the Imperial Council), the State's top administrative body, which shed light upon the institutions, implementations and the history, in many similar fields, of the Ottoman State, are recorded are called Books of Muhimmah, the decisions wherein being called Huqum (Decree).

The Ottoman administration preferred the growth in population and, in that context, the concerned authorities were encouraged. Apart from transferring the population to vacant fertile soils, immigration movements were urged, too. The objective that lies under such type of policy could be accepted to be the requirement for bigger population in order to realize comprehensive military, financial, economic, social and political policies.

The aim of this archive research is to obtain some knowledge as regards to which factors people immigrated into and emigrated from the Ottoman State within the coverage of the population movements. How did it administer the relations on the borders with Asia and Europe as well as with the neighboring states within this context? How was the external migration assessed as a means of attracting or transferring population? The replies of such questions were sought.

\footnotetext{
"Asst. Prof., Istanbul Commerce University, Vocational School. harslan@ticaret.edu.tr "* Asso. Prof., Marmara University, Faculty of Economics, Department of Economics. rahmideniz@marmara.edu.tr
} 
The 16th century was preferred as it was the age wherein the Ottoman State was the most developed from many aspects. The research was carried out on basis of the Muhimmah Books. The findings were evaluated in light of the documentary examples. Although we were to be satisfied with a limited number of original archives documents, the study was supported with secondary references.

Having given the transcription of the Muhimmah Books, which were written in the Calligraphy of Divan, the summary and main theme thereof was provided in current Turkish as well. Examples were taken from the Ottoman State's lands in Asia and Europe.

The following order was observed in showing the Muhimmah Books as reference: the numbers of Muhimmah Books, the page numbers, the numbers of decrees and the Hegira dates of decrees along with the equivalent dates thereof by the Gregorian Calendar.

After the introduction, the aim, method, archive research and literature review, findings, evaluation and result, the list of references was provided and the study was completed.

The backbone of the study is composed of the Books of Muhimmah. It is possible to realize a scientific contribution by benefitting from this historical past and this original source in order to develop and improve as an individual, the society, the state and civilization as well as to promote the structure and quality of the population. With this contemplation, the population movement that could be related to external migration was researched in the $\mathrm{Mu}$ himmah Books numbered 5, 6, 7, 12, 31, 32 and 35.

In fact, the movement from the Ottoman lands to the East began to be observed with the emergence of Shah Ismail and the period earlier. Shah Ismail, after the advice of his followers and consultants, invited the adherents of Safawites in Asia Minor to join him. Afterwards, the peasant and nomad Turcoman of Asia Minor obeyed this invitation with great enthusiasm and thus played a great role in the foundation and rise of the Safawite State as army officers and administrators.

In the decree sent to the Beg of Trabzon, it was ordered that measures be taken with the mention that 30 Qizilbash Chapnis from the Town of Kürtün emigrated to the land of Safawites after the Treaty of Peace, adding that others were continuously collecting Nuzur (animals for sacrifice) and that they might emigrate for good. Likewise, it was further ordered that the disbelieving ones of them be captured and conveyed to Istanbul, reminding that those innocuous ones should not be disturbed with that excuse, in which respect an emigration subject to political and denominational preference was in question. 
That attitude of the brother of Kubad Beg, Ruler of Imadiyyah, viz. Bahram, who is said not to give up plotting mischief and to have visited such places as Urmiyyah, Tabriz, and Kazvin in the Land of the Safawites, passing by the City of Van in the company of forty men in his suite, owing to both the dispute with his brother and his dissatisfaction with the Sanjaq given to him by the Ottoman State was evaluated as his preference for Rafizi Sect and siding with the Qizilbashs.

In another document it is highlighted that a peace treaty actually continued to be valid between the Ottoman State and the Safawite administration at the time, adding that Sheikh Haydaride Kara Beg, who allied with the Safawite administration, drew population from those villages subject to the Ottoman State, having trespassed the mentioned treaty, thereby causing external migration. Nevertheless, it is stated that that Ottoman subjects migrated to the Safawite land was an act of oppression and injustice, which was not given consent to by the Sultan.

Meanwhile, the issue that the peoples of Bozulus and Karaulus, who were deprived of their land on a large soil, inclusive of Diyarbekir, Van, Erzurum, Rum (Sivas) and Zulkadirlu (Maraş) for the alleged reasons that their places were being given to others by Sanjaqbegs with such excuses as that they were vacant and forlorn without any title-deeds, would be dispersed in the Safawite land was negotiated and thereby the authorities and kadis (judges) of the said cities were demanded that they should take the required measures, emphasizing that if they emigrated to the Safawite land there would be considerable decrease in the revenues of the State.

Such decrees as wherein it was ordered that the double taxation be ended because those people of other nations that emigrated across the border (viz. to Iran) since Sancakbegs seized their yaylaqs (summer pastures) illegally to give them to others as Timars were subjected to taxes under various titles; that those nations that were expelled from their yaylaqs unjustly should be ensured to return to their soils within the Ottoman land, thereby being restored their summer pastures; that it was ensured that the said people return to their summer pastures and winter pastures in peace without them being caused any injustice by any manner at all; that the justice should be secured; that those that cased oppression and injustice should be punished with due justice; and that a detailed report be submitted to the Sultan were conveyed to the Beylerbegs of Diyarbekir and Erzurum.

According to the letter written by the Ottoman administration to the ruler of Luristan, Muhammedi Mirza, he was demanded, with the mention of the land - of those lands that had been given to Gazi Khan - that had been allocated to him for his taking refuge and settling therein with his family, subjects 
and tribe, whereby he was demanded that he defend the Religion of Islam, that he should exert due endeavor and effort in observing the enemies of the Ottoman State and protecting the State. In truth, the Ottoman administration favored population growth by providing places and opportunities to those that wished to immigrate to the Ottoman land with their tribe, family and adherents.

In that decree that was sent to those Begs that were affiliated to the Beylerbeg of Baghdad, the begs in the lands around the border were warned that those tribes and groups, who were called Ulusat, from the place called Upper Janib in Iran, who wanted to come into the Ottoman land, should be prevented from entering the Ottoman country because they were rebellious, mischief-makers and evil-doers, putting emphasis thereby on the point that such people were not to be allowed to enter the country.

In 1565, the Erdel Kingdom was subject to the Ottoman State. Meanwhile, the Rulers of Sabash and Logosh were subject to the Kingdom of Erdel. The said rulers announced that they would exempt those that wished to settle in their vicinity from taxation up to three years, whereby they aimed to promote the population of their lands. In that context, of the Ottoman subjects, most of the non-Muslims that had settled in around Vidin, Fath Al-Islam and Danube were about to migrate to those lands. It is understood that some of them had gone there. In the said decree, the king was demanded that he order that his officers should find those subjects that had migrated to the said places and ensure their return to their former places.

When those that went to collect Kharaj in the aforesaid four locations saw that the Kharaj was deficient and investigated into the matter, in the City of Tamashwar, they came to understand that the said taxes fixed per home were entered into Books while, as they were written per capita in other places, the subjects there migrated to the City of Tamashwar, thus warning that people were not to be allowed to migrate from that place to the latter; that it be ensured that those that had gone there be returned; also warning that effort should be exerted to attract subjects from Sabash and Lagos and Majar to Tamashwar and to the aforesaid place if it was wished that the country be made prosperous and developed. Also, it was stated that no good could be achieved by evacuating the population on one hand and transferring it to the other side, while filling the population vacation in that new place with that transferred population, for which reason it was advised that in place of attracting population from the inland places, a flow of population should be ensured from the outside to the inside.

That the population left the country owing to such reasons as tyranny, injustice and pressure that were against justice was not deemed appropriate. 
In that context, it was underlined that a contrary policy of population should be followed if the aforesaid city was wished to develop, whereby ensuring population to immigrate from abroad into that city to settle there.

These documents being taken into consideration, it is seen that the Ottoman State preferred the immigration from the neighboring countries, both in the east and the west, as the foreign population policy in order to contribute to the development of the production, security, public works, peace and welfare. Furthermore, the promotion of the immigration was given significance by the State from the aspects of making the concerned regions of the country well populated and prosperity as well as the revivification, development and the manufacturing of values economically and financially. Meanwhile, in pursuit to this very understanding, the emigration was discouraged lest the opponent countries should be strengthened in their economy, military force, politics, administration, security and human resources.

It is understood that some of the immigrations and emigrations related to the population movement were seasonal trans-border migrations while some others were caused by interparty conflicts and the dissatisfaction with the administrators' practices.

Again, it is seen that, within the coverage of the foreign economy, just as the Ottoman State followed such a policy wherein it allowed the import of economic sources to ensure self-subsistence in return of which it restricted, subjected to permit or totally banned the export of arms, mounts, provisions, munitions and the like articles of defensive and vital value, as the population policy, in a synchronized manner thereby, it did not give permission to emigration but encouraged immigration in a controlled and preferential method.

Given that the development of a country and growth thereof in all aspects are based on the adequacy of the population and economic sources, it is also today advisable that such population policies are implemented as whereby the populations are encouraged to live where they are ensuring that they stay in the country through the fulfillment of the conditions of welfare without hindering human rights and freedoms. Currently, due to what is known as the brain-drain, whereby the qualified people of the underdeveloped countries emigrate to the developed countries, the intellectual and scientific levels as well as the level of the perception of life fall in those countries wherefrom people emigrate. On the other hand, those countries that get migration attain to an advantageous position from sociological, economic, military, strategic and many other similar aspects, as result of which those countries wherefrom people emigrate could be changed into semi- or full-colonies, thus being debased into a dependent position. 


\section{Kaynakça / References}

Arşiv Kaynakları

Mühimme Defteri: 6, 206-207, 445. 26 Rebi'ü'l-evvel Sene 972/ 1.11.1564

Mühimme Defteri: 5, 108, 252. 25 Safer Sene m.[973]/ 21.9.1565

Mühimme Defteri: 7, 170, 448. 11 Cemaziye'l-evvel Sene 975/13.11.1567

Mühimme Defteri: 7, 848, 2321. 29 Rebi'ü'l-evvel [976]/ 21.9.1568

Mühimme Defteri: 12, 42, 86. 23 Ramazan Sene 978/ 18.02.1571

Mühimme Defteri: 32, 20, 72. 7 Ramazan Sene 985/ 18.11.1577

Mühimme Defteri: 35, 262, 664. 27 Receb Sene 986/ 10.10.1577

Mühimme Defteri: 31, 388, 863. 13 Şaban Sene [986]/ 15.10.1578

Mühimme Defteri: 32, 376-377, 668. 19 Rebi'ü'l-evvel Sene 986./27.05.1578

Mühimme Defteri: 5, 513, 1401. 17 Ramazan Sene 993 / 12.9.1585

\section{Basilı Kaynaklar}

Akbayar, N. (2001). Osmanlı Yer Adları Sözlüğ̈̈. İstanbul: Tarih Vakfı Yurt Yayınları.

Akkayan, T. (1979). Gög ve Değişme. İstabul: 1979.

Arslan, H. (2001). 16. Yüzyıl Osmanlı Toplumunda Yönetim, Nüfus, İskân, Gö̧ ve Sürgün. İstanbul: Kaknüs Yay.

Geza, D. (1999). Osmanl Macaristaninda Toplum, Ekonomi ve Yönetim. 16. Yüzyılda Simontornya Sancağı. İstanbul: Tarih Vakfi Yurt Yayınları.

Djafar-Pour, A. (1977). Nadir Şah Devrinde Osmanl-İran Münasebetleri. Yayımlanmamış Doktora Tezi, İstanbul: İstanbul Üniversitesi Edebiyat Fakültesi, Osmanlı Müesseseleri ve Medeniyeti Tarihi Kürsüsü.

Emecen, F. ve Şahin, İ. (1994). II.Bayezid Dönemine Ait 906/1501 tarihli Abkam Defteri. İstanbul: TDAV.

Genç, M. (2013). Osmanlı Imparatorluğu’nda Devlet ve Ekonomi. İstanbul: Ötüken Yayınları.

Genç, Y. İhsan ve arkadaşları. (2010). Başbakanlık Osmanlı Arşivi Rehberi. İstanbul: Başbakanlık Basımevi.

Kaya, M. (2011). Çepniler Tarihi Serüveni ve Giresin-Espiye Yöresinin Kültür Kökenleri. İstanbul: Togan Yayınları.

Kurtuluş, B. (1999). Amerika Birleşik Devletlerine Türk Beyin Göçü. İstanbul:. Alfa Yayınlar1.

Kurtuluş, R. (2003). Luristan. İslam Ansiklopedisi, c. 27, s. 227. Ankara: TDV.

Küpeli, Ö. (2010). Irak-1 Arapta Osmanl1-Safevî Mücadelesi (XVI-XVII. Yüzyıllar). History Studies. Middle East Special Issue, s. 228-230.

Sami, Ş. (1996). Kâmûs u'l-A'lâm. Ankara: Kaşgar Neşriyat.

Sami, Ş. (2004). Kamus- 1 Türki. İstanbul: Kapı Yayınları.

Sümer, F. (1998). Çepni. Íslam Ansiklopedisi, c. 8. İstanbul: Türkiye Diyanet Vakfı

Tuna, K. (1981). Yurt Dışına Iş̧̧ Gönderme Olayının Sosyolojik Eleştirisi. İstanbul:

İstanbul Üniversitesi

Edebiyat Fakültesi Basımevi.

Uzunçarşıll, İ. H. (1973). Osmanlı Tarihi, c. 3, k.1. Ankara: TTK..

Uzunçarşıll, İ. H. (1977). Osmanlı Tarihi, c. 3, k.2. Ankara: TTK. 


\begin{tabular}{|c|c|c|c|c|c|c|c|c|c|c|}
\hline 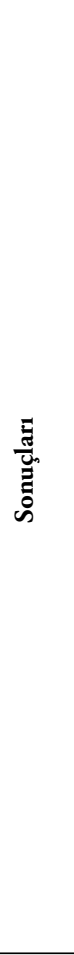 & 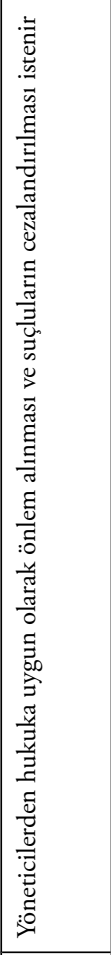 & 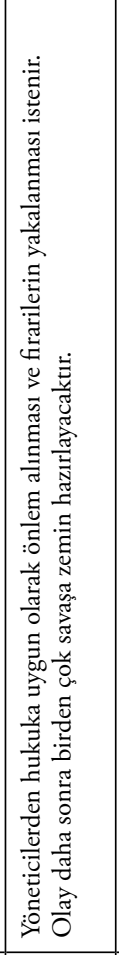 & 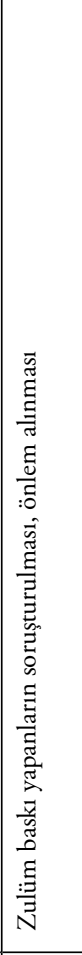 & 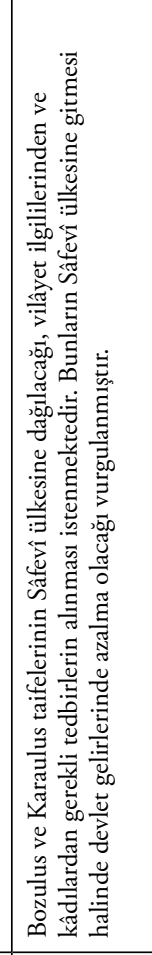 & 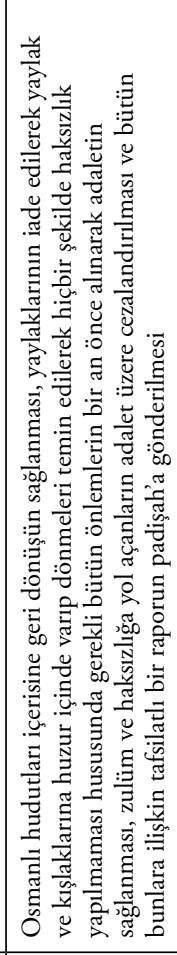 & 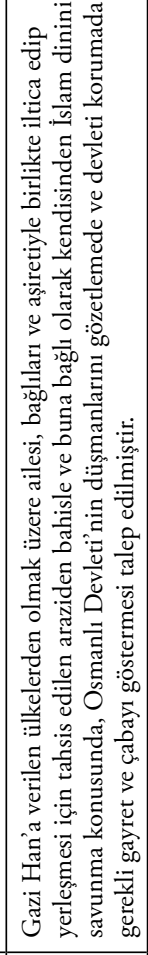 & 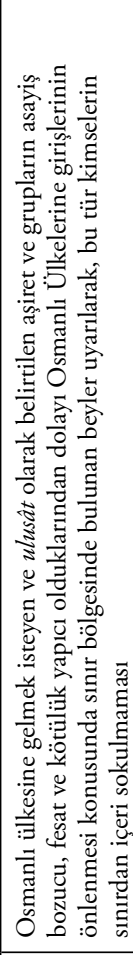 & 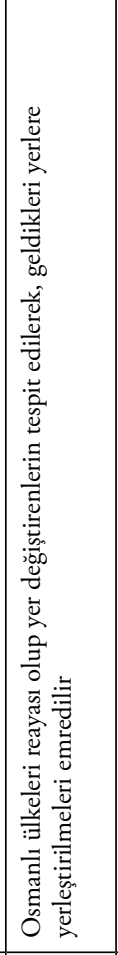 & 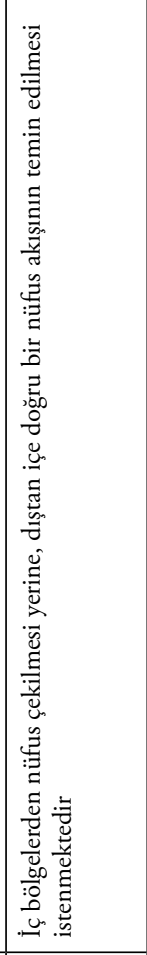 & 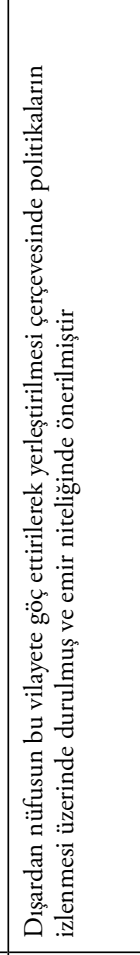 \\
\hline : & 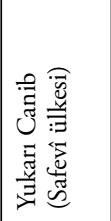 & 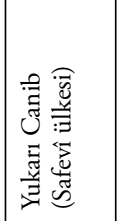 & 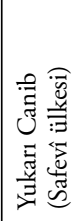 & 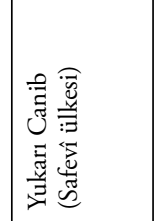 & 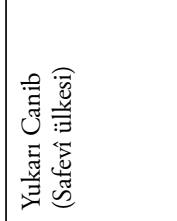 & 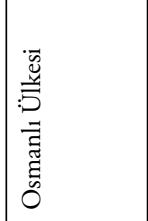 & 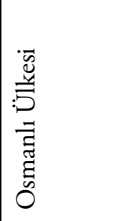 & 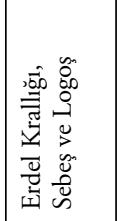 & 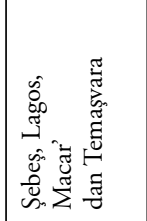 & 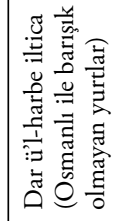 \\
\hline & 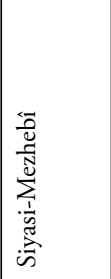 & 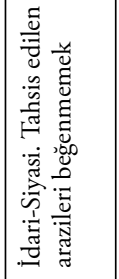 & 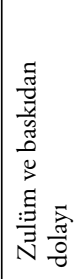 & 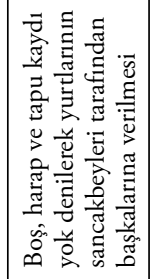 & 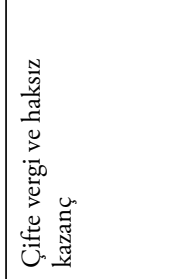 & 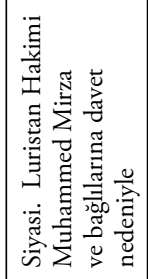 & 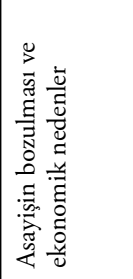 & 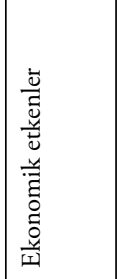 & 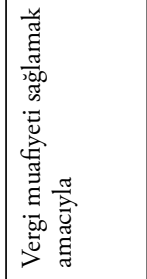 & 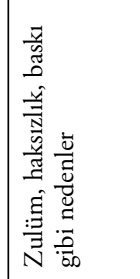 \\
\hline 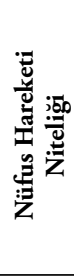 & 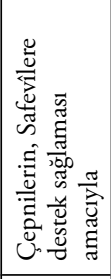 & 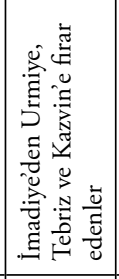 & 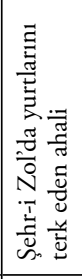 & 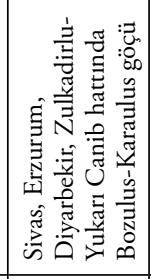 & 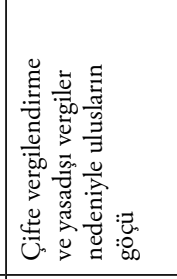 & 苑 & 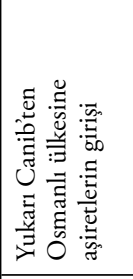 & 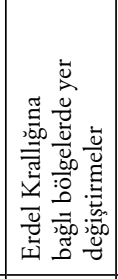 & 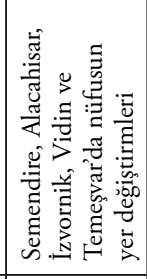 & 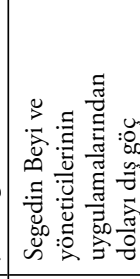 \\
\hline 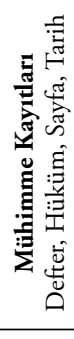 & 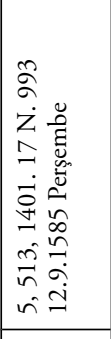 & 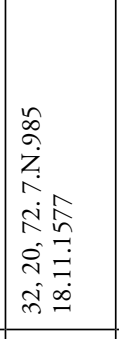 & 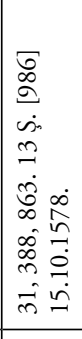 & 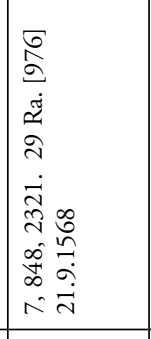 & 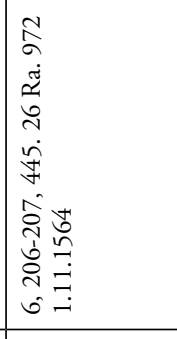 & 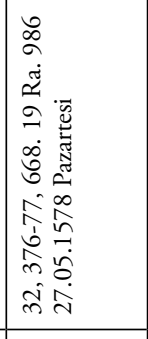 & 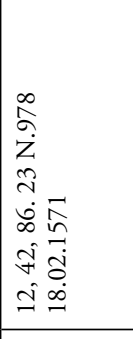 & 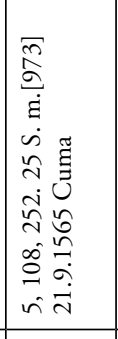 & 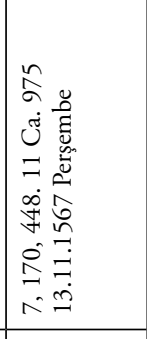 & 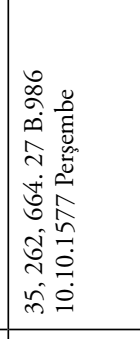 \\
\hline 焉文 & - & $\sim$ & $m$ & w & n & 0 & $r$ & $\infty$ & $\sigma$ & $\circ$ \\
\hline
\end{tabular}

